\title{
Effect of sample plot size and shape on estimates of structural indices: A case study in mature silver birch (Betula pendula Roth) dominating stand in Järvselja
}

\author{
Kobra Maleki*and Andres Kiviste
}

\begin{abstract}
Maleki, K., Kiviste, A. 2015. Effect of sample plot size and shape on estimates of structural indices: A case study in mature silver birch (Betula pendula Roth) dominating stand in Järvselja. - Forestry Studies | Metsanduslikud Uurimused 63, 130-150. ISSN 1406-9954. Journal homepage: http://mi.emu.ee/forestry.studies
\end{abstract}

\begin{abstract}
Structural indices and characteristics have often been employed for assessing different aspects of forest stands. In order to assess the performance of such measures in forest sample plots of different size and shape, the current study is based on a data set for a relatively large ( $1 \mathrm{ha})$ silver birch dominated stand, and five simulated planar point patterns (a Poisson process, two clustered and two regular patterns) with similar intensity of points distributed on an area equal to the silver birch stand as reference stands. The analyses was based on repeated samplings of the stands, with randomly placed circular or square shaped plots of different sizes, with area ranging from 0.007 to 0.636 ha. Similar centre positions were considered for plots of different shapes, but the locations of the plot centres differed with size, so that plots of different sizes were able to cover the maximum possible area of reference stands. Some structural indices accounting for one or four nearest neighbours, and also the Point-pair correlation function was then quantified for each random sample plot. We used standard deviation and the differences of the mean estimates from the expected values to assess the sensitivity of the structural measures to the size and shape of sampling plots. The results indicated the significant effect of plot size and shape on structural indices. The correlation between plot size and estimates precision was positive, and small plots, regardless of their shapes, showed big variation among them while circular plots often provided more accurate estimates. Even though, as expected, expanding the plots increased the precision of the neighbourhood-based indices' estimates (spatial measures), and also resulted in inaccurate estimates for some reference stands, depending on the arrangement of trees/points within that stand.
\end{abstract}

Keywords: Betula pendula, spatial indices, point patterns, circular plot, square plot, nearest neighbour.

Authors' address: Estonian University of Life Sciences, Institute of Forestry and Rural Engineering, Department of Forest Management, Kreutzwaldi 5, Tartu 51014, Estonia; *e-mail: Kobra.Maleki@emu.ee

\section{Introduction}

Forests are complex ecosystems and their structural attributes are of great importance (Franklin et al., 2002; Kint et al., 2004). Spatial alignment of individual trees and distribution patterns of their size and species are known as major components of forest stand structure (Gadow \& Hui, 1999;
Lingua et al., 2008). The structural properties of forests are believed to be related to their ecosystem functioning (Naumburg \& DeWald, 1999; Bobiec, 2002; Sallabanks et al., 2002; Frolking et al., 2009). Evidently, growth of trees is influenced by the species composition, spatial structure, and dynamics of forest stands and also anthropogenic effects (Navarro-Cerrillo et al., 
2013), and in return the dynamic processes of growth and disturbance are reflected in the structural components of forests (Rice et al., 2004; Unger et al., 2013).

Regarding the importance of the mentioned components in analysing forest ecosystems and their dynamics, numerous indices and statistical techniques for quantifying stand structure have been developed and compared (e.g. Gleichmar \& Gerold, 1998; Kint et al., 2000, 2003; Pommerening, 2002). The majority of structural indices have been divided into two main groups: non-spatial and spatial measures. Some specific structural properties of forests, such as tree diameter distribution and tree species composition belong to the first group, which do not need any spatial reference and often they are quite simple to assess, and can be used for more complex assessments (Palace et al., 2015). The second group is based on positions of trees and it can be subdivided into the following subcategories: individual tree parameters based on neighbourhood relations, spatial measures of forest stand structure at stand level, and continuous functions of inter-tree relations (Pommerening, 2002). Neighbourhood relations of trees, based on their nearest-neighbours, account for small-scale differences and are appropriate, as well as easy to calculate and interpret (Kint et al., 2003). Stand level spatial indices often describe aspects of variability of individual tree locations within stands by a single value whilst continuous functions are more complex, using techniques to examine the second-order effects, and take all possible inter-tree distances within the stand into account (Dale, 2000; Pommerening, 2002; Law et al., 2009). Forests in different development stages and conditions, when considering the trees as stationary points, represent different point processes. For instance, (1) older forests may present a regular pattern, where trees have been thinned out earlier, either due to inter- and/or intra-specific competition leading to self-thinning, or because of management activities, (2) a clustered pattern may be found in young forests consisting of trees with heavy seeds or with any heterogeneous conditions forming trees in groups, and finally (3) a random pattern, Poisson process, is common in most forests (Tomppo, 1986; Pommerening, 2002), and it is a situation between two recent patterns (Pommerening, 2006).

Since spatial indices require information about tree positions, and obviously the collection of such data is expensive and time-consuming (Kint et al., 2004). Considering the facts that forest spatial pattern heterogeneity at different scales is an important component of their structural complexity (Churchill et al., 2013) and the plot size has a direct effect on the assessment of general stand characteristics, such as stand density and stand basal area (Corona et al., 1998), appropriate sampling methods, either in size or by shape, must be used (e.g. Füldner, 1995; Pommerening \& von Gadow, 2000). Various sampling approaches can be properly applied, considering the specific objectives of designing forest monitoring plots, in order to define the degree of precision and accuracy required through a benefit-cost analysis (Corona \& Marchetti, 2007; Travaglini et al., 2013; Lombardi et al., 2015).

To date, several data sources have been established in Estonia for forest growth assessment and yield modelling, the main sources being those of the National Forest Inventory (NFI) and the Estonian Network of Forest Research Plots (ENFRP). The NFI sample plots are circular with systematic design, and cover the entire area of Estonia, and are planned in a five-year cycle. The sampling intensity is the same throughout the country, having a cluster distribution with the aim of increasing the efficiency of the survey, and keeping the accuracy requirements at a national level. Trees are measured in the NFI sample plots with radii of 7 and $10 \mathrm{~m}$, for temporary and permanent plots, respectively (Adermann, 2010). The ENFRP consists of 
729 permanent plots, containing the data for all the main forest types in Estonia (Kiviste et al., 2015). The permanent plots are circular with a radius ranging from 7 to $30 \mathrm{~m}$ and are measured at intervals of every five years.

For this study, in order to check how well the stand structure variables can be estimated within the Estonian plots, we carried out an experiment for a detailed investigation to view the influence of the sampling plot size on the assessment of some structural indices for a one-hectare silver birch dominated plot and five simulated point patterns. Since circular and square-shaped sample plots are commonly used in forest mensuration (van Laar \& Akça, 2007), the square plots of varying size were also implemented, and compared with the circular plots for the forest structural study. Therefore, the main objective of our study is to assess the sensitivity of the structural indices' estimates to the size and/or shape of the sample plots, within the varying structural complexity of a silver birch dominated stand and five other simulated point patterns.

\section{Material and Methods}

\section{Study area}

The study area consisted of one hectare $(100 \mathrm{~m} \times 100 \mathrm{~m})$ stand which was dominated by 54 years old silver birch trees, established for Radiation Model Intercomparison (RAMI) study (Kuusk et al., 2013), located in Järvselja Training and Experimental Forest Centre; compartment JS228 (latitude: $58^{\circ} 15^{\prime} 54.60^{\prime \prime}$, longitude: $\left.27^{\circ} 16^{\prime} 57.97^{\prime \prime}\right)$. Within the stand the growth conditions are good and the total number of 968 trees on the typical brown gley-soil was re-measured in 2013, and with the first measurement done in 2007. The RAMI stand consists primarily of deciduous tree species including: $57 \%$ silver birch (Betula pendula Roth), 29.5\% common alder (Alnus glutinosa (L.) Gaertn.) and
$11 \%$ aspen (Populus tremula L.). A thinning operation was carried out in the stand during September-October 2004. Based on the social status of the trees, the mentioned deciduous species formed the first layer, and the second tree layer mostly consisted of small leafed linden/lime (Tilia cordata Mill.) and Norway spruce (Picea abies (L.) H. Karst.) while the understory vegetation was dominated by a mixture of several grass species (Kuusk et al., 2013).

\section{Sampling simulation}

The analysis of the effect of sample plot size and shape consisted of several simulated samplings of the stand with randomly placed plots. For our circular sample plots, with 41 different radii ranging from 5 to $45 \mathrm{~m}$ and increasing by one meter, were then selected so that the Estonian plot sizes were included within this range. For every plot size, 1,000 random centres were independently generated. Also, depending on radius, a buffer zone of trees near the stand borders was considered when determining the sample plot centres, with its width equal to the sample plot radius. Subsequently, the simulated sample plots could be always, thoroughly improvised inside the RAMI stand. Square plots were formed around each random centre defined for the circular plots with the restriction that they cover an area equal to the area of the corresponding circular plot.

A forest stand can be reduced to a finite set of points to represent the horizontal locations of trees in the stand, and the assumption is that the two-dimensional alignment of tree positions in a stand can be described by a point process (Penttinen et al., 1992). Therefore, in order to test the sensitivity of structural indices to different point patterns, five different planar point patterns were generated with the condition that these virtual plots cover an area equal to the RAMI stand, and with almost the same intensity. In those patterns, each point defined by its position can represent a tree in the virtual plot using 


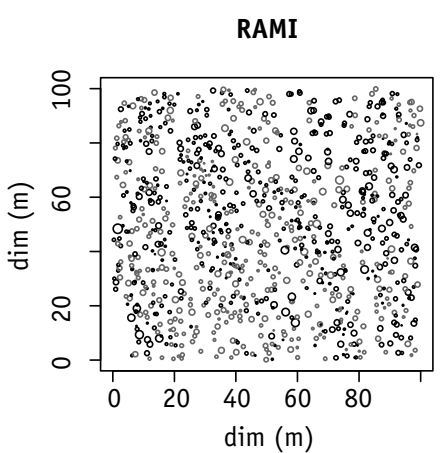

Reg2

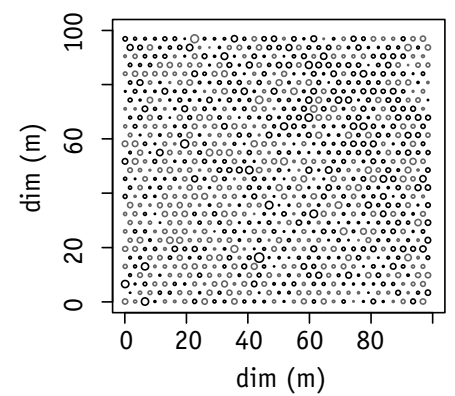

Ran

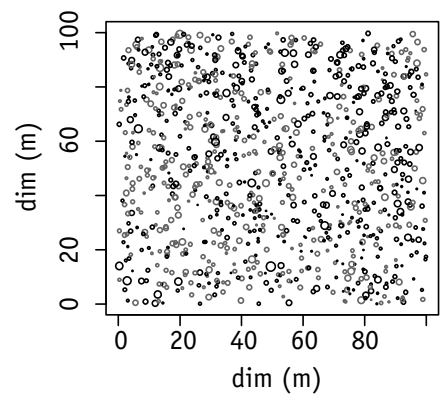

Cl1

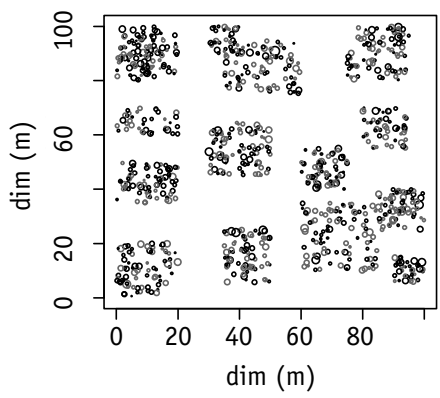

Reg1

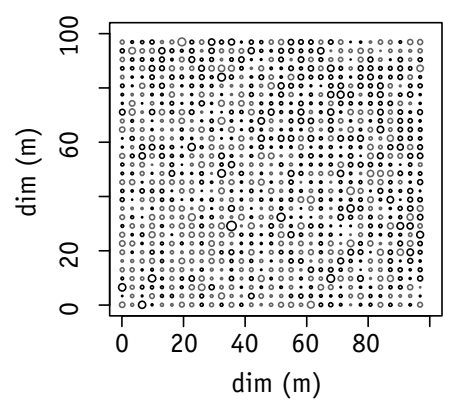

$\mathrm{Cl} 2$

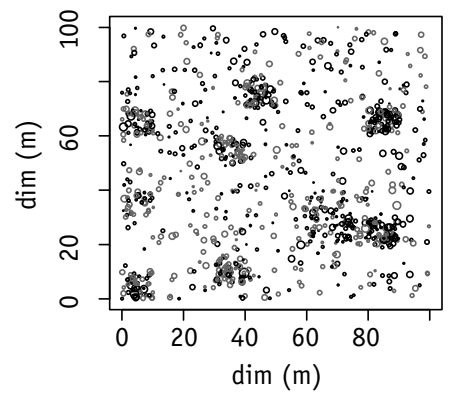

Figure 1. Reference stands patterns including RAMI stand and five simulated point patterns; grey circles of different sizes are silver birch trees with their corresponding size and black circles are other species.

Joonis 1. Uurimisala RAMI puistu ja viie simuleeritud virtuaalse puistu puude paigutuse mustrid; hallid ringid vastavad arukasele, mustad ringid teistele puuliikidele ja ringi raadius on võrdeline puu diameetriga.

two-dimensional Cartesian coordinates (Pommerening \& Stoyan, 2006). The simulated patterns are: 1) a Poisson process or random pattern (Ran); 2) an extreme clustered pattern $(\mathrm{Cl} 1) ; 3)$ a moderate clustered pattern $(\mathrm{Cl} 2)$, where both cluster centres follow the Poisson process and the cluster points are randomly distributed in circles of various radii around the centres; or 4) \& 5) two types of regular patterns (Reg1 \& Reg2). Also in order to keep the similar species composition and diameter distribution, the diameter and species identity of trees within the RAMI stand were assigned to the points in the simulated stand. For this step, the trees in the RAMI stand and the points in the simulated patterns were ranked based on their distances and angles from the stand centre, and the points got the diameter and species identity of trees in the RAMI stand having similar ranks. Therefore, the next step was to explore the effect of the sample plot size and shape on structural indices' estimates, and we were also able to test the effect of different spatial alignment of trees. For the five simulated patterns a sampling method similar to the RAMI stand with the same plot centres was applied. Therefore the RAMI stand and five simulated patterns, as shown in Figure 1, formed our reference stands for this study.

\section{Structural indices}

Structural indices applied on simulated sample plot data are presented in Table 1. Five indices describe stand spatial structure by single values, and are based on 
Table 1. List of structural indices used for the study.

Tabel 1. Uurimuses kasutatud struktuuriindeksite loetelu.

\begin{tabular}{|c|c|c|c|}
\hline $\begin{array}{l}\text { Variable } \\
\text { Muutuja }\end{array}$ & $\begin{array}{l}\text { Description } \\
\text { Kirjeldus }\end{array}$ & $\begin{array}{l}\text { Calculation } \\
\text { Arvutusvalem }\end{array}$ & $\begin{array}{l}\text { Type } \\
\text { Tüüp }\end{array}$ \\
\hline agg & $\begin{array}{l}\text { Aggregation index } \\
\text { Agregatsiooniindeks }\end{array}$ & $\frac{L_{o b s}}{E(L)}, E(L)=\frac{1}{2 \times \sqrt{\mathrm{n} / \mathrm{A}}}$ & NN1 \\
\hline ddf & $\begin{array}{l}\text { Diameter differentiation index } \\
\text { Diameetri diferentseerumisindeks }\end{array}$ & $1-\frac{\min \left(d b h_{i^{\prime}} d b h_{j}\right)}{\max \left(d b h_{i^{\prime}} d b h_{j}\right)}$ & NN1 \\
\hline ua & $\begin{array}{l}\text { Uniform angle index } \\
\text { Puude paiknemisindeks }\end{array}$ & $\frac{1}{n} \sum_{j=1}^{n=4} w_{j}$ where $w_{j}=\left\{\begin{array}{l}1 \text { if } \alpha<360^{\circ} / 5 \\
0 \text { if } \alpha \geq 360^{\circ} / 5\end{array}\right.$ & NN4 \\
\hline $\mathrm{ddm}$ & $\begin{array}{l}\text { Diameter dominance index } \\
\text { Diameetri domineerimisindeks }\end{array}$ & $\frac{1}{n} \sum_{j=1}^{n=4} v_{j}$ where $v_{j}=\left\{\begin{array}{l}1 \text { if } d b h_{\mathrm{j}}<d b h_{i} \\
0 \text { if } d b h_{j} \geq d b h_{i}\end{array}\right.$ & NN4 \\
\hline ming & $\begin{array}{l}\text { Species mingling index } \\
\text { Liikide segunemisindeks }\end{array}$ & $\frac{1}{n} \sum_{j=1}^{n=4} m_{j}$ where $m_{j}=\left\{\begin{array}{l}1 \text { if } \text { Species }_{j} \neq \text { Species }_{i} \\
0 \text { if } \text { Species }_{j}=\text { Species }_{i}\end{array}\right.$ & NN4 \\
\hline$g(r)$ & $\begin{array}{l}\text { Point-pair correlation function } \\
\text { Radiaaljaotuse funktsioon }\end{array}$ & $g(r)=\frac{\lambda}{\lambda_{0}}$ & $\mathrm{~N}-\mathrm{N}$ \\
\hline
\end{tabular}

Notes: $L_{\text {obs }}$ and $E(L)$ are the mean distance to the first nearest neighbour and the mean nearest neighbour distance in a stand in the case of completely random tree locations, respectively; $n$ and $A$ are the number of trees and area of the observation window, respectively; $d b h_{i}$ and $d b h_{j}$ are the diameter at breast height of the reference tree $i$ and its neighbour $j$, respectively; $\alpha$ is the angle pointing away from the reference tree to neighbours; $\lambda$ is the intensity of points at distance $r$ from an arbitrary point and $\lambda_{0}$ is the expected intensity for a Poisson process.

Märkused: $L_{\text {obs }}$ ja $E(L)$ on puu keskmine kaugus lähima naabrini ja lähima naabri oodatav keskmine kaugus puude täiesti juhusliku paigutuse korral, kus $n$ and $A$ on vaatlusakna puude arv ja pindala; $d b h_{i} j a d_{b h}$ on vaadeldava puu $i j a$ naaberpuu $j$ rinnasdiameetrid; $\alpha$ on vaatluspuu ja kahe naaberpuu vaheline nurk; $\lambda$ on puude tihedus juhuslikust punktist kaugusel $r j a$ $\lambda_{0}$ on puude oodatav tihedus puude täiesti juhusliku paigutuse korral.

nearest-neighbour relations as follows: the aggregation index (Clark \& Evans, 1954) and diameter differentiation index (Füldner, 1995; Pommerening, 2002) using only the nearest neighbour while diameter dominance (von Gadow \& Hui, 2002; Aguirre et al., 2003), uniform angle index (Hui \& von Gadow, 2002) and species mingling (Füldner 1995; Aguirre et al., 2003) are single tree based indices accounting for 4 nearest neighbours.

The aggregation index (agg) describes the aspects of the variability of tree locations in the stand and is defined as:

$\operatorname{agg}=\frac{L_{o b s}}{E(L)}, E(L)=\frac{1}{2 \times \sqrt{\mathrm{n} / \mathrm{A}}}$ where $L_{o b s}$ is the mean distance to the first nearest neighbour, $E(L)$ is the mean nearest neighbour distance in a stand, in the case of completely random tree locations, $A$ is the area of sample plots, as observation windows, and $n$ is the number of trees. The expected value of the aggregation index in the case of completely random tree locations is equal to 1 , where values less than 1 indicate a clustered distribution of trees, and values greater than 1 point to a tendency to being regular.

Diameter differentiation index (ddf) as a single-tree based measure of biodiversity of tree dimensions illustrates the spatial distribution of tree sizes as follows: 


$$
d d f_{i}=1-\frac{\min \left(d b h_{i^{\prime}} d b h_{j}\right)}{\max \left(d b h_{i^{\prime}} d b h_{j}\right)}
$$

where $d b h_{i}$ and $d b h_{j}$ are diameter at breast height for tree $\mathrm{i}$ and its nearest neighbour $\mathrm{j}$. Values equal to zero indicate equal size of neighbouring trees.

Diameter dominance index $(d d m)$ is another measure of biodiversity of tree dimensions and is calculated as follows:

$d d m_{i}=\frac{1}{n} \sum_{j=1}^{n=4} v_{j}$

where $v_{j}=1$ if the neighbour for a tree has smaller dbh than that tree, otherwise $v_{j}=0$. The $d d m$ value ranges between 0 and 1 and values equal to 1 refer to the dominance of the tree to its nearest neighbours by $\mathrm{dbh}$.

Uniform angle index $(u a)$ defines the degree of regularity of the spatial distribution of tree positions in a stand, and it is considered as a single-tree based alternative to the $a g g$ (von Gadow et al., 1998):

$u a_{i}=\frac{1}{n} \sum_{j=1}^{n=4} w_{j}$

If $\mathrm{a}_{0}=360^{\circ} / 5$ and $\mathrm{a}$ is the angle pointing away from a tree to its neighbours; $w_{j}=1$ when $a<a_{0}$, otherwise $w_{j}=0$. The $u a$ value ranges between 0 and 1, where value equal to 0 refers to regularity and value equal to 1 shows clustering.

Species mingling index (ming) defines the degree of spatial segregation of the tree species in a stand, and gives the proportion of four nearest neighbours which do not belong to the same species as the reference trees:

$\operatorname{ming}_{i}=\frac{1}{n} \sum_{j=1}^{n=4} m_{j}$

where $m_{j}=1$ if the neighbour for a tree is of a different species, otherwise $m_{j}=0$. The ming value ranges between 0 and 1 , where values equal to 0 refer to the tendency of species to be segregated and values equal to 1 show that a tree is surrounded by other species. Compared to agg, singletree based indices do not result in a single value, but in a value for each tree within the stand, for describing a whole stand by a specific index, the mean value for that stand is calculated.

Finally, in order to describe the spatial structure of the RAMI stand and the five simulated point patterns on a continuous basis, not only by a single value but also with a function, the radial distribution function (Diggle, 1983) or on the other hand, the point-pair correlation function (Cressie, 1993), depending on the inter-tree distance, was calculated:

$g(r)=\frac{\lambda}{\lambda_{0}}$

where, $\lambda$ is the intensity of points at a distance $r$ from an arbitrary point and $\lambda_{0}$ is the expected intensity for a Poisson process. The interpretation is similar to $a g g$, where $g(r)=1$ refers to randomness, where spatial distribution of trees/points are not correlated, $g(r)<1$ suggests inhibition between points and $g(r)>1$ shows clustering.

\section{The edge effect correction}

An important issue which should be addressed when dealing with spatial indices is the edge effect of trees standing near the edge of a sample plot, and the fact that the detected neighbours may not be their actual or real nearest neighbours. Ignoring this effect could result in inaccurate statistical estimates. To eliminate this error a border method was applied (Ripley, 1981). To apply this method a buffer zone was implemented near the stand boundary. Depending on the indices, for a tree located within or near the stand border, the distance from its $\mathrm{n}^{\text {th }}$ nearest neighbour (e.g. first or fourth nearest neighbour) and the distance of that tree to the border were 
checked, and then the tree was excluded from the spatial indices calculation if its distance to the border was shorter. However, that tree could only serve as the nearest neighbour to other trees (Pommerening \& Stoyan, 2006). This method guarantees the removal of all edge effects and, in comparison with other methods, it is simple to use (Kint et al., 2004).

\section{Statistical analyses}

In order to evaluate the variation of structural indices for each size class and shape, the mean and the variance of each index were calculated. For reference stands, the expected values of any specific index, regarding the actual area of reference stands covered by sample plots, were computed. Since circular plots do not cover the areas near the corners of the reference stands, due to their circular shape and the square shape of reference stands, the uncovered areas (increasing with circular plot size) were considered and excluded when calculating the expected values. The effect was different for square sample plots. Since the attempt was to keep the same plot centres for circular and square sample plots with equal size, the square plots did not cover the areas of reference stands near the borders. In order to avoid the plots outside the stand area, for each sample plot size a buffer zone with a width equal to the circular plot radius was considered, and the dimensions of square plots were slightly smaller than circular plot diameters with equal size.

Standard deviation $(s d)$ and the differences of the mean estimates from the expected values were calculated to highlight the effect of the sample plot size and/ or shape on estimate precision and accuracy, respectively. The calculation of $s d$ is straightforward and the differences of the mean estimates from the expected values indicate the inaccuracy of the mean of the thousand sample plots estimations to measure the true values of structural indices. All calculations and analyses were performed using the R statistical software.

\section{Results}

Table 2 presents exact values of structural indices for all six one-hectare plot reference stands. In the case of the circular sample plots, the differences between exact values and expected values of structural indices were small $(<1 \%)$ for all reference stands, except for clustered patterns $\mathrm{Cl} 1$ and $\mathrm{Cl} 2$, varying up to 2.3 percent. In the case of the square sample plots, the differences between exact values and expected values

Table 2. Summary of reference stands and their structural measures used for this study.

Tabel 2. Uuritud struktuuriindeksite oodatavad väärtused RAMI puistus ja viies simuleeritud virtuaalpuistus.

\begin{tabular}{lccccccc}
\hline $\begin{array}{l}\text { Reference stands / } \\
\text { Puistu }\end{array}$ & $\mathrm{N}$ & $\mathrm{D}$ & agg & ddf & ua & ddm & ming \\
\hline RAMI & 968 & 20.132 & 1.04 & 0.315 & 0.603 & 0.514 & 0.610 \\
Ran & 968 & 20.132 & 1.01 & 0.303 & 0.539 & 0.501 & 0.654 \\
Reg1 & 961 & 20.079 & 2.00 & 0.397 & 0.000 & 0.499 & 0.661 \\
Reg2 & 961 & 20.132 & 2.00 & 0.373 & 0.500 & 0.521 & 0.689 \\
Cl1 & 968 & 20.132 & 0.67 & 0.329 & 0.699 & 0.495 & 0.702 \\
Cl2 & 968 & 20.132 & 0.84 & 0.306 & 0.706 & 0.496 & 0.647 \\
\hline
\end{tabular}

Notes: $\mathrm{N}$ is number of trees on the one hectare reference stand; $\mathrm{D}$ is the mean square diameter of the reference stand.

Märkused: N on ühe hektari suuruse puistu puude arv, D on puistu ruutkeskmine diameeter. 
agg
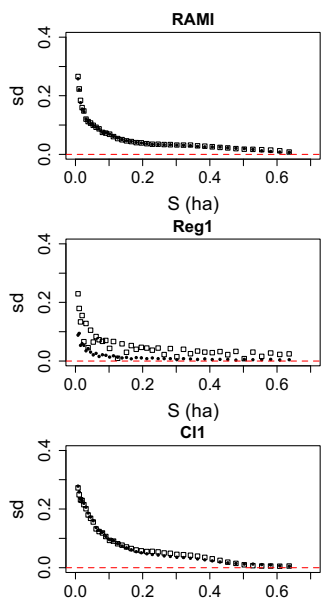
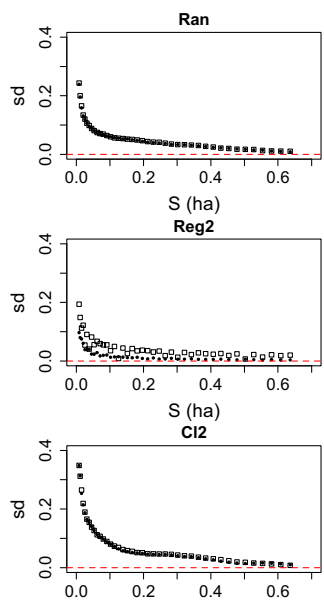

ddf
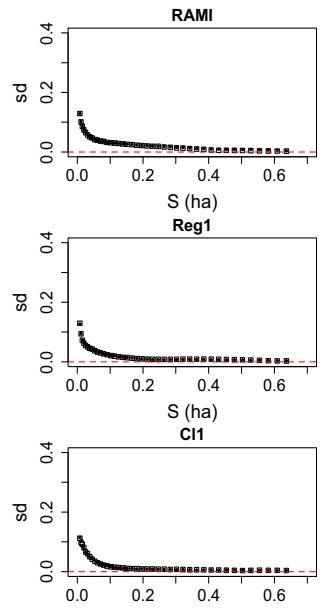
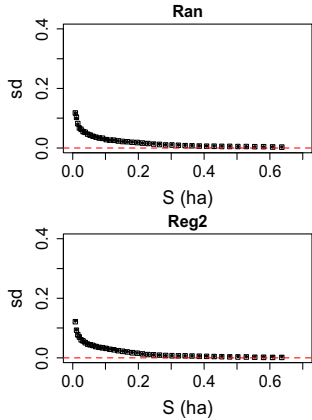

$\mathrm{S}$ (ha)

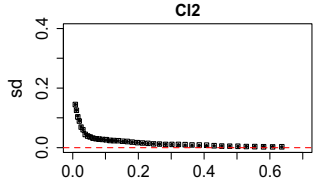

Figure 2. Standard deviations of structural indices counting for the first nearest neighbour, where $\bullet$ and $\square$ signs represent the standard deviations for circular and square plots, respectively.

Joonis 2. Lähima naaberpuu statistikal põhinevate struktuuriindeksite hinnangute standardhälbed sõltuvana proovitüki pindalast ja kujust (märgid $\bullet j a \square$ vastavad ringile ja ruudule).

of structural indices were even smaller $(<0.4 \%)$. Figure 1 shows that the greater difference in the case of the circular sample plots with a clustered pattern is caused due to the occurrence of the clusters in the corners, when compared with the area excluded from the quantifications of expected values, and a considerably larger number of points, specifically for bigger radii, were excluded.

Variation of the statistical estimates quantified by the standard deviation $s d$ are presented in Figure 2 for the indices based on the first nearest neighbour, and in Figure 3 for the indices based on four nearest neighbours. Variation of structural indices estimates declined asymptotically with increasing sample plot size in six different reference stands. Even though, compared to the circular plots, there is evidence of a slightly bigger variation of the estimate of $a g g$, for the square sample plots in almost all reference stands, specifically in regular patterns. Notice that in case of uniform angle index $u a$ the regular patterns Reg1 and Reg2 caused different sd trend than that from the other simulated patterns. In the case of a regular pattern, $u a$ remained constant for all sample plot sizes and shapes, 0 for Reg1 and 0.5 for Reg2, resulting in $s d=0$.

The differences of the mean estimates from the expected values of structural indices for different sample plot size and shape are illustrated in Figure 4 for the indices based on the first nearest neighbour and Figure 5 for the indices based on four nearest neighbours. The spatial arrangement of trees/points defined by agg, shows less inaccuracy for circular plots in all reference stands. In RAMI, random and regular reference stands inaccuracy declines with the sample plot area increasing up to $0.1 \mathrm{ha}$; however an underestimation of $a g g$ (or overestimation of clustering) is seen for the reference stand $\mathrm{Cl} 1$ when the plot area expands. In $\mathrm{Cl} 2$, the differences of the mean estimates from the expected values for agg first decrease with the plot increasing in size up to around 0.1 ha and 

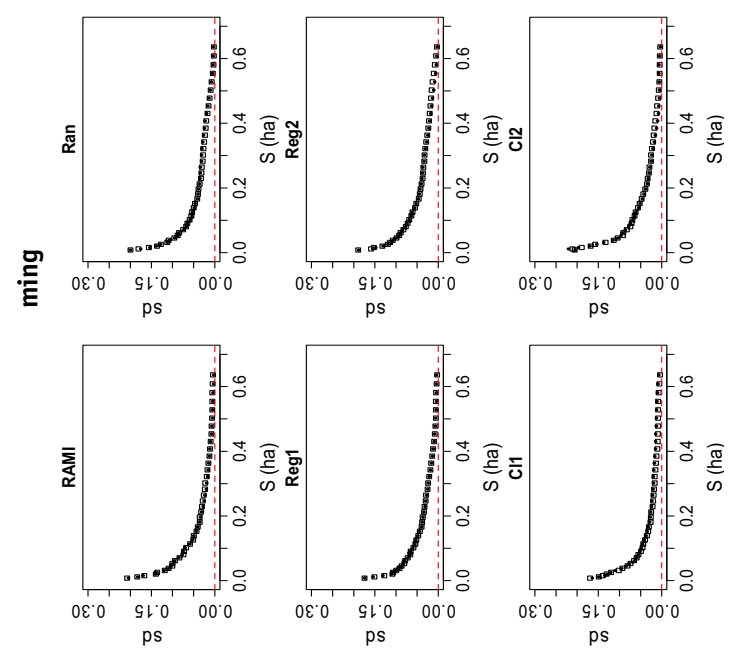

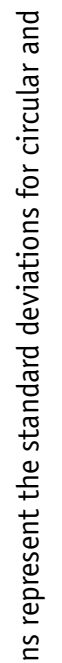

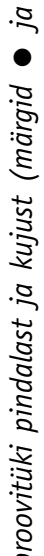
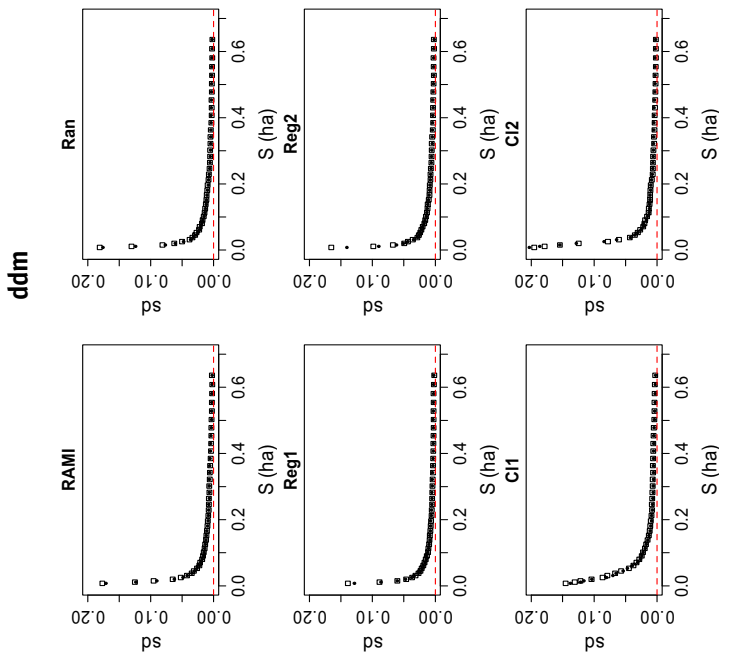

$\frac{0}{\frac{2}{3}}$

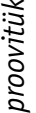

ई

$\frac{5}{n}$

ป
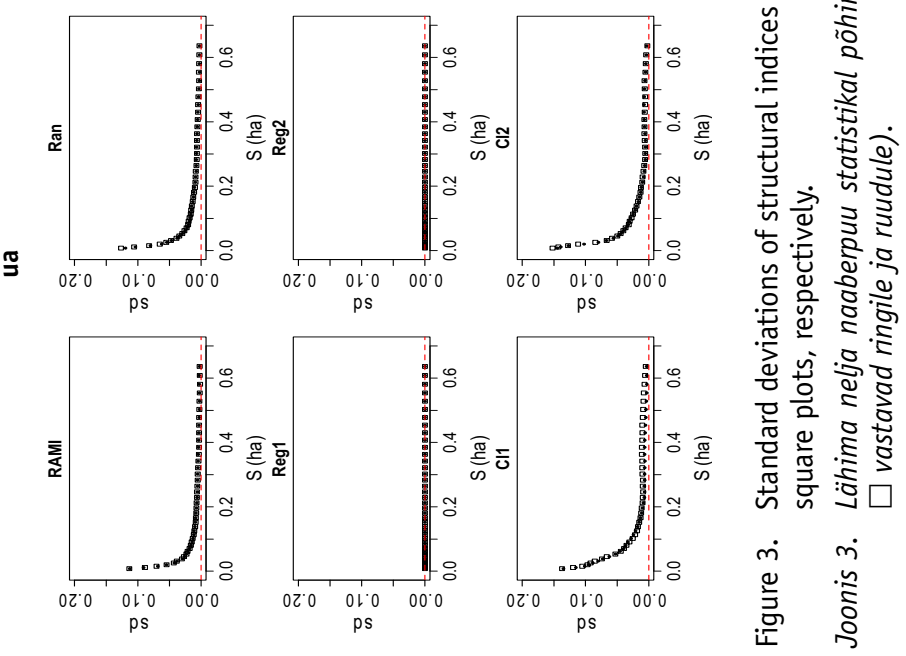


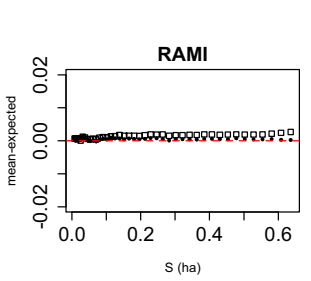

agg
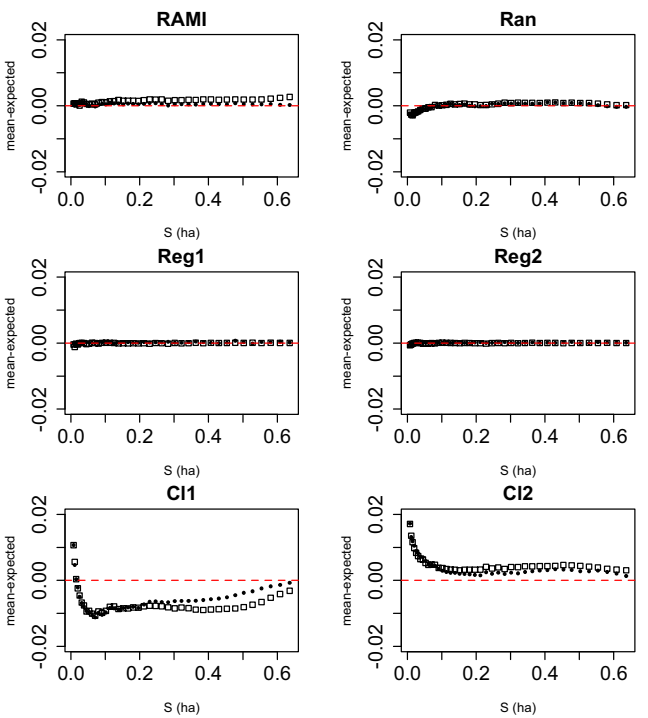
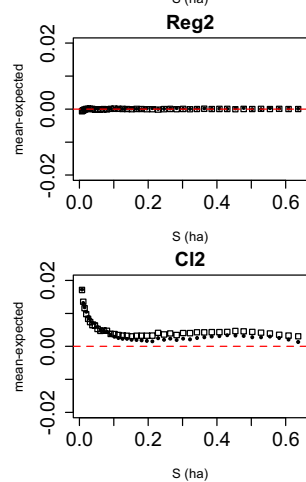
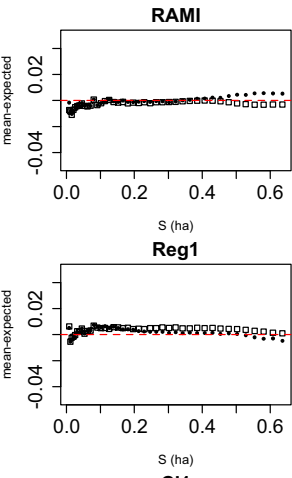

Cl1

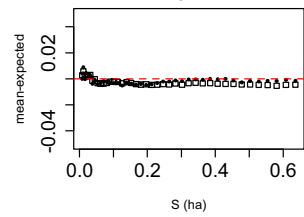

ddf
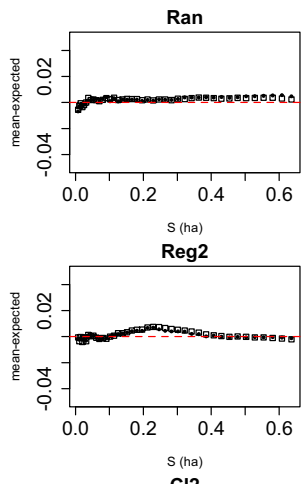

$\mathrm{Cl} 2$

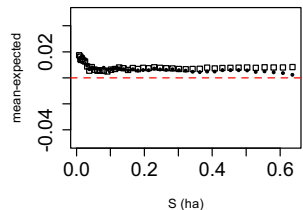

Figure 4. The differences of the mean estimates from the expected values of structural indices counting for the first nearest neighbour, where $\bullet$ and $\square$ signs represent the differences for circular and square plots, respectively.

Joonis 4. Lähima naaberpuu statistikal põhinevate struktuuriindeksite hinnangute keskmine erinevus oodatavast väärtusest sõltuvana proovitüki pindalast ja kujust (märgid $\bullet$ ja $\square$ vastavad ringile ja ruudule).

for sample plots bigger than 0.1 ha the differences start to increase again, however when the plot areas exceed 0.5 ha, the structural variables of those plots start converging to the structural values of the reference stand. Also, the estimate accuracy of $d d f$ for reference stands, RAMI, Reg1 and Reg2, increased slightly with sample plot size, regardless of their shapes and the differences of the mean estimates from the expected values reached the minimum for sample plot size of $0.40-0.45$ ha. The differences of the mean estimates from the expected values at estimating the indices based on four nearest neighbours were very small for all reference stands (less than $4 \%)$. Small sample plots produced mainly satisfactory results and, more or less, circular and square plots exposed the similar trends. Although the bigger sample plots slightly estimated a greater mixture of different species in a neighbourhood with all reference stands expect Cl1, accuracy increased by enlarging the plots' size above 0.4 ha. Besides, similar to $s d$, the measure of $u a$ remained constant with the size and/or shape of sample plots, always 0 for Reg1 and 0.5 for Reg2, therefore, the differences of the mean estimates from the expected values were equal to zero.

Figure 6 illustrates the information about the maximum distances within which trees/points may have direct interactions. As shown the pair correlation function resulted in thoroughly different pictures for considered reference stands. The pair correlation function in the RAMI stand shows a distance limit of approximately $6 \mathrm{~m}$, where trees intend to be inhibited, and do not tend to be located in shorter distances within the stand. In further distances up to $10 \mathrm{~m}$, they show a more clustering behaviour, and after that, their spatial arrangement approaches to randomness. As expected the $g(r)$ values for random patterns are around 1 and the 


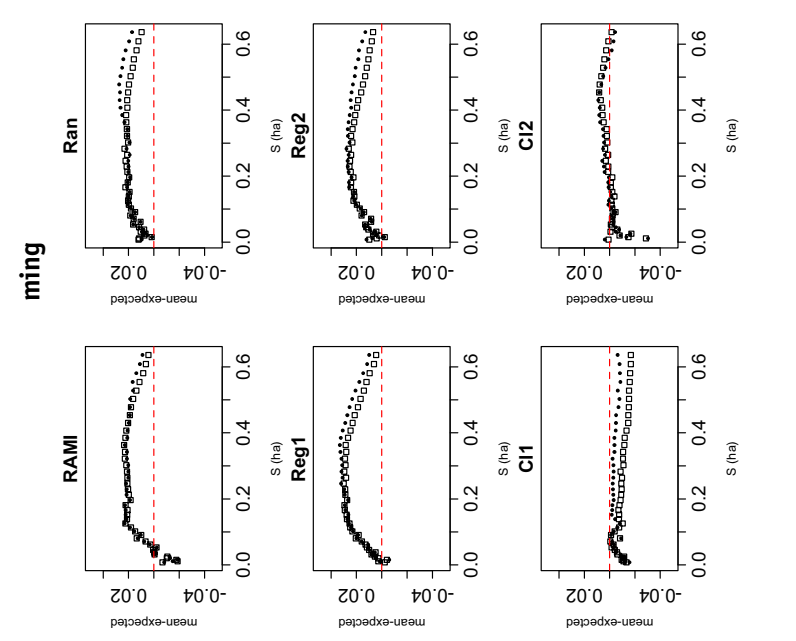

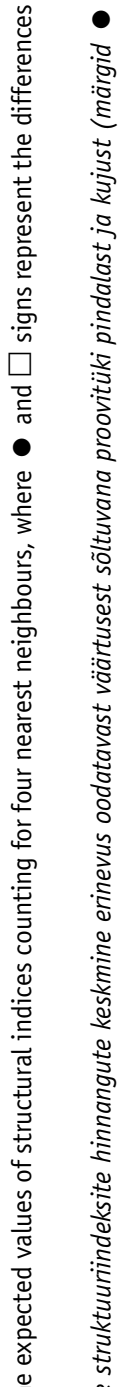

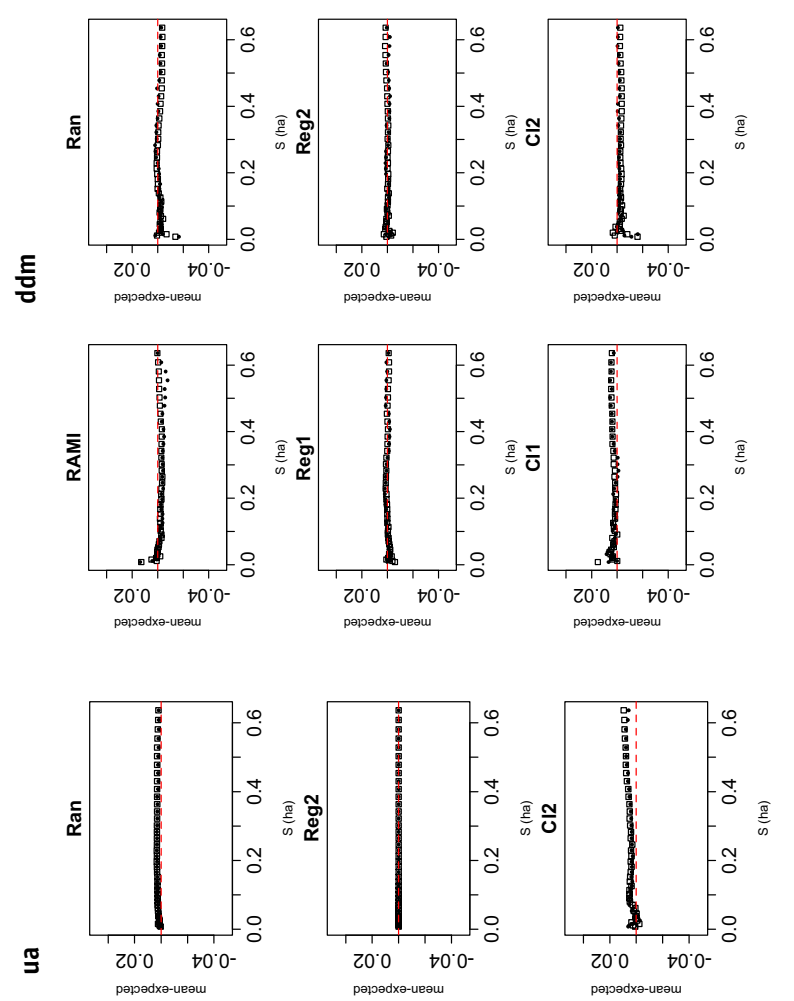

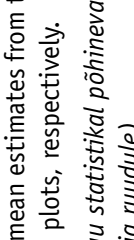

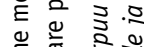

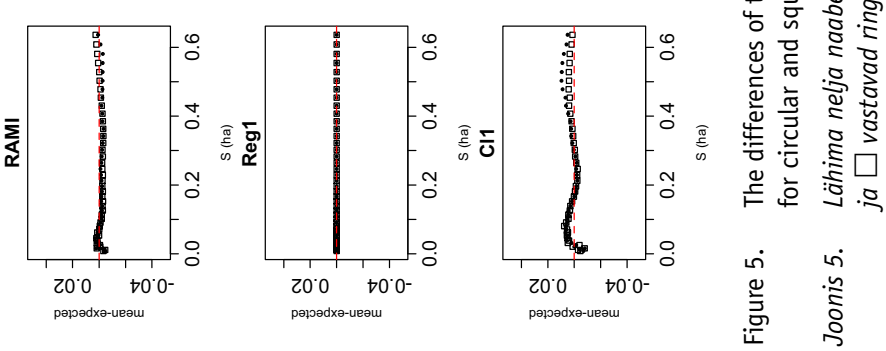



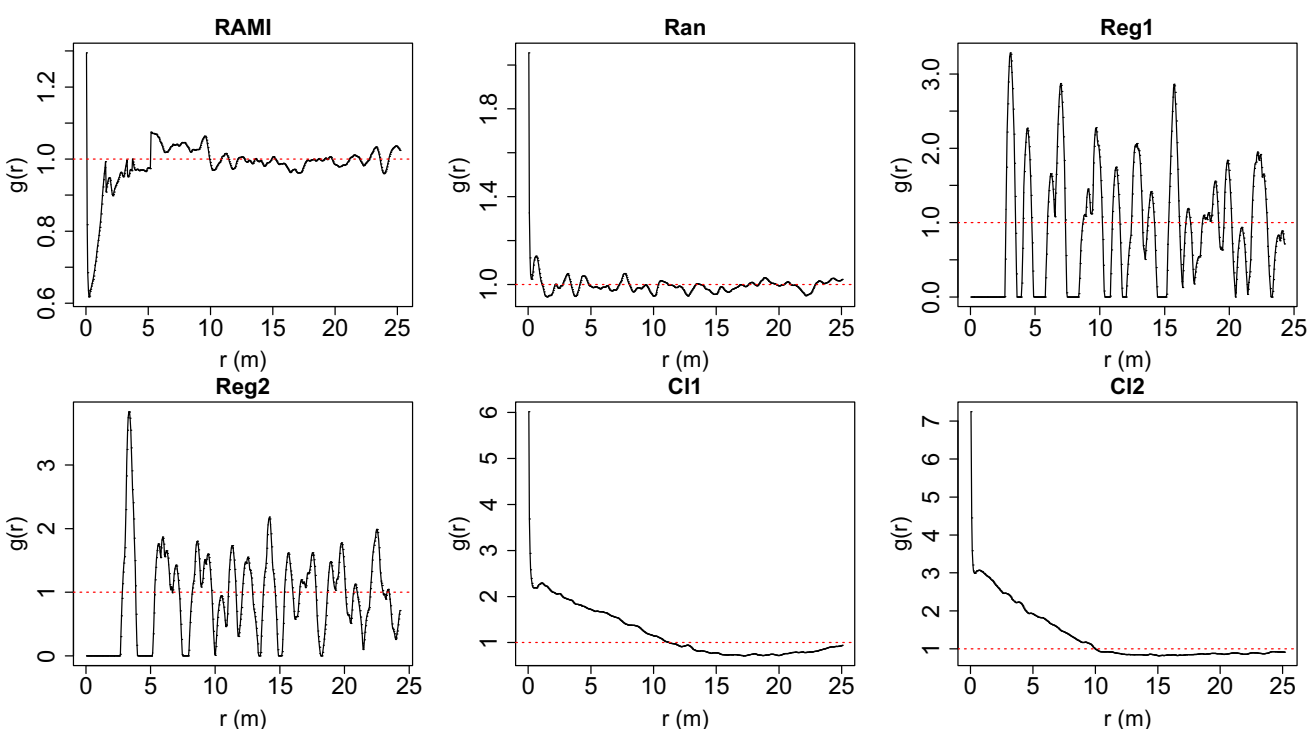

Figure 6. The pair correlation function, $g(r)$, for the RAMI stand and five simulated point patterns, where the dotted lines indicate complete randomness.

Joonis 6. Radiaaljaotuse funktsioon $g(r)$ uurimisala RAMI puistu ja viie simuleeritud virtuaalse puistu jaoks. Punktiirjoon vastab puude täiesti juhuslikule paigutusele.

cluster patterns appear to have the values of correlation function greater than 1 , up to inter-tree distances of 10-12 m, and after that critical distance, the pair correlation function behaves similar to the Poisson process for the mentioned patterns. Finally, the pattern of fluctuations in $g(r)$ values for regular reference stands reflects the current spacing between points within those patterns.

\section{Discussion}

This study evaluated the estimation errors of several spatial structural indices for different sizes and shapes of sampling plots using a silver birch dominated stand located in Järvselja, RAMI, and five different planar point patterns. The analyses revealed that the estimation precision of random sample plots increased with size for circular and square plots. This finding is well documented based on many other studies (e.g. Johnson \& Hixon, 1952; Freese, 1960;
Gray, 2003; Frazer et al., 2011; Næsset et al., 2015). Also as explained, some fluctuations for precision estimates of structural indices with increasing sample plots size in regular and clustered patterns were indicated. This finding is consistent with some previous studies where they concluded that the spatial scale of point patterns other than random affects the mentioned relationship between size and estimation precision (Reich \& Arvanitis, 1992) and depending on the stand structure and management, the sampling errors and inaccuracy could often increase considerably (Pommerening \& von Gadow, 2000; Kint et al., 2004).

The relative locations of trees/points within reference stands were described by spatial indices of $a g g$ and $u a$. The results of the statistical analyses for the two indices were slightly different due to different algorithms of calculating $a g g$ and ua. Where ua shows the expected trend of reduction in $s d$ and inaccuracy with increasing size in most cases, as explained, some exceptions were evident for $a g g$ in 
RAMI and clustered patterns. However, when the variations declined with plot size, the bigger sample plots (> $0.01 \mathrm{ha}$ ) in $\mathrm{Cl} 1$ pattern underestimated the $a g g$, which means a larger degree of clustering. Also sample plots bigger than 0.12 ha in RAMI and C12 slightly overestimated the aggregation, where smaller sample plots ( $<0.12$ ha) in $\mathrm{Cl} 2$ estimated more randomness than the actual existing clustering. As already explained $a g g$ is the ratio of average observed distances from the first nearest neighbour to the expected distance for a Poisson point process of the same intensity (see eq.1) and depending on the area that the sample plots cover, and the intensity of trees/points, the mentioned expected distance may be smaller, or bigger, than that for the one-hectare plot. Besides, this fact is reflected with the pair correlation values bigger than $1(\mathrm{~g}(r)>1)$ for clustered patterns, showing that inter-tree interactions exist up to the distances of 10-12 m, and after that $g(r)$ curves reach 1 , or even slightly less. Therefore, smaller plots fail to capture the actual points interacting. Various methods exist to represent spatial clustering (e.g. Anselin, 1996; Boots \& Getis, 1988) and irrespective of the measurement employed, analyses are always subject to ecological fallacy by size, or other effects (Wrigley et al., 1996). Subsequently, in order to achieve appropriate measurements, special consideration must be devoted to the scale of the general layout of the underlying process, and the overall distribution of points within the selected stand. The uniform angle index obtained for different reference stands were in accordance with their aggregation values, and behaved as expected: values between 0.5 and 0.6 refer to randomness, more than 0.6 show clustering, and less than 0.5 indicate regularity. However these distinctions may vary slightly (Albert, 1999, p. 67).

In the RAMI stand, the measures of structural indices ming and $d d m$, while only considering the four nearest neighbours, revealed that trees of different species and diameter sizes were assigned as neighbours, and the stand had quite a mixed structure. The values of two recent indices, bigger than 0.5 (see Table 2), indicated that, on average, each tree had two neighbours of different species, and the tree was larger than at least two of its immediate neighbours. However, the variation in the stem sizes of two immediate neighbours illustrated by $d d f$ was rather small. This outcome seems acceptable for a silver birch-dominated stand, since as a pioneer tree species (Fischer et al., 2002), silver birch is intolerant to shade, and the most favourable condition for this tree species is growing as a dominant tree with relatively less competitive surroundings (Hynynen et al., 2010). Additionally, self-thinning due to negative interactions between neighbouring trees would result in a structure similar to the Poisson process with trees located randomly within a stand or even more regularly (Stoyan \& Penttinen, 1998; Pommerening, 2002). The estimates of the structural indices considering the diameter and species identity for the five other reference stands were similar to the RAMI stand because of the method applied to assign $d b h$ and species to points in this study. The aggregation and uniform angle measures for the RAMI stand when compared to those for random and regular patterns showed the same trend. Also, in shorter inter tree distances (up to $6 \mathrm{~m}$ ), the pair correlation function values smaller than $1(\mathrm{~g}(r)<1)$ revealed that at those distances fewer trees were observed than what would be expected under random conditions. Regarding the compliance of inter-tree distance of $6 \mathrm{~m}$ with the estimated crown diameter of silver birch trees ranging from 1.5 to $5.8 \mathrm{~m}$, the competition or/and thinning must cause this inhibition as explained earlier in this study, and also in other similar studies quantifying forest structure (e.g. Pommerening, 2002).

The results obtained for structural estimates in the RAMI stand showed that the small plots with the area about 0.15 ha 
were able to provide quite accurate estimates, and increasing the plot size did not significantly reduce the differences of the mean estimates from the expected values. Although, the smaller plots can show large variation among them, they captured the spatial heterogeneity of the RAMI stand more efficiently than larger plots, and similar behaviour was also observed in Lombardi et al. (2015) when quantifying the effect of sample size on some structural indices in old-growth forests. Subsequently, changes can be detected by increasing the number of smaller plots as an alternative to enlarging the sample plot size (Salk et al., 2013). Several practical matters must be considered when adopting research sample plots. The introduction of efficient plots, either by size or by shape, allows the reduction of the total area assigned for sampling, or also lessens the total efforts and cost to measure the plot while maintaining the desirable accuracy. However, the influences of the studied traits are, of course, consequential. Several studies on the impact of plot size and/or shape on various measures of forest stands have also acquired considerable gains with small plots, while the efficiency analyses for larger plots proved impotent (e.g. Conkle, 1963; Loo-Dinkins \& Tauer, 1987; Haapanen, 1992; Lombardi et al., 2015). Although there are reports of opposite gains due to various reasons and different traits that were investigated (e.g. Corona et al., 1998; Gray, 2003).

When applying spatial structural indices an important issue to be considered is the edge effects, where the neighbourhood relationships are not truly shown for trees near the plot boundary due to the uncertainty of the neighbours' selection, as actual neighbours may lie outside the plot. Also depending on the algorithms of indices, when they count only for one nearest neighbour, or four nearest neighbours, this effect varies with shape and the reference stands' patterns. As the results of this study showed, although the inaccuracy of the estimate of circular and square plots are similar, the estimation errors among plots of the same size are more likely less for circular plots. When exploring the effect of shape, in most cases, circular sample plots come up with more accurate estimates. This attitude may be explained by the ratio of the perimeter to the surface area of monitoring plots, which is smaller for circular plots compared with square ones. Consequently, the edge effect becomes more significant with decreasing the plot size, and also for square plots, as more trees will be excluded from the indices' calculations (Pommerening, 2002). Despite several methods developed (e.g. Monserud \& Ek, 1974; Martin et al., 1977; Donnelly, 1978) or tested (e.g. Radtke \& Burkhart, 1998; Pommerening \& Stoyan, 2006) in order to eliminate the edge effect, there is no overall solution that can be applied to all structural indices and plot shapes for stands with whatever pattern. However, the outcome of the current study presented slightly different estimates of structural measurements of reference stands for different plot shapes. In general, applying the circular plots provided much better approximations of considered structural indices for the studied RAMI stand and the simulated point patterns.

\section{Potential variation of structural indices on Estonian forest sample plots}

The distributions of indices' estimations applying sample plots with radii of 10 $\mathrm{m}$, more common in NFI, and radii of 20 $\mathrm{m}$, more common in ENFRP, to measure structural properties in the RAMI reference stands are compared in Figure 7. As it is shown, and also explained earlier, when the sample plot radius increases from 10 to 20 $\mathrm{m}$, the variation of sample plots when calculating structural indices decreases, and therefore the larger sample plots provide more accurate measures of the structural indices for the RAMI reference stand.

The agg and $u a$ values of RAMI are very close to randomness (see Table 2), 

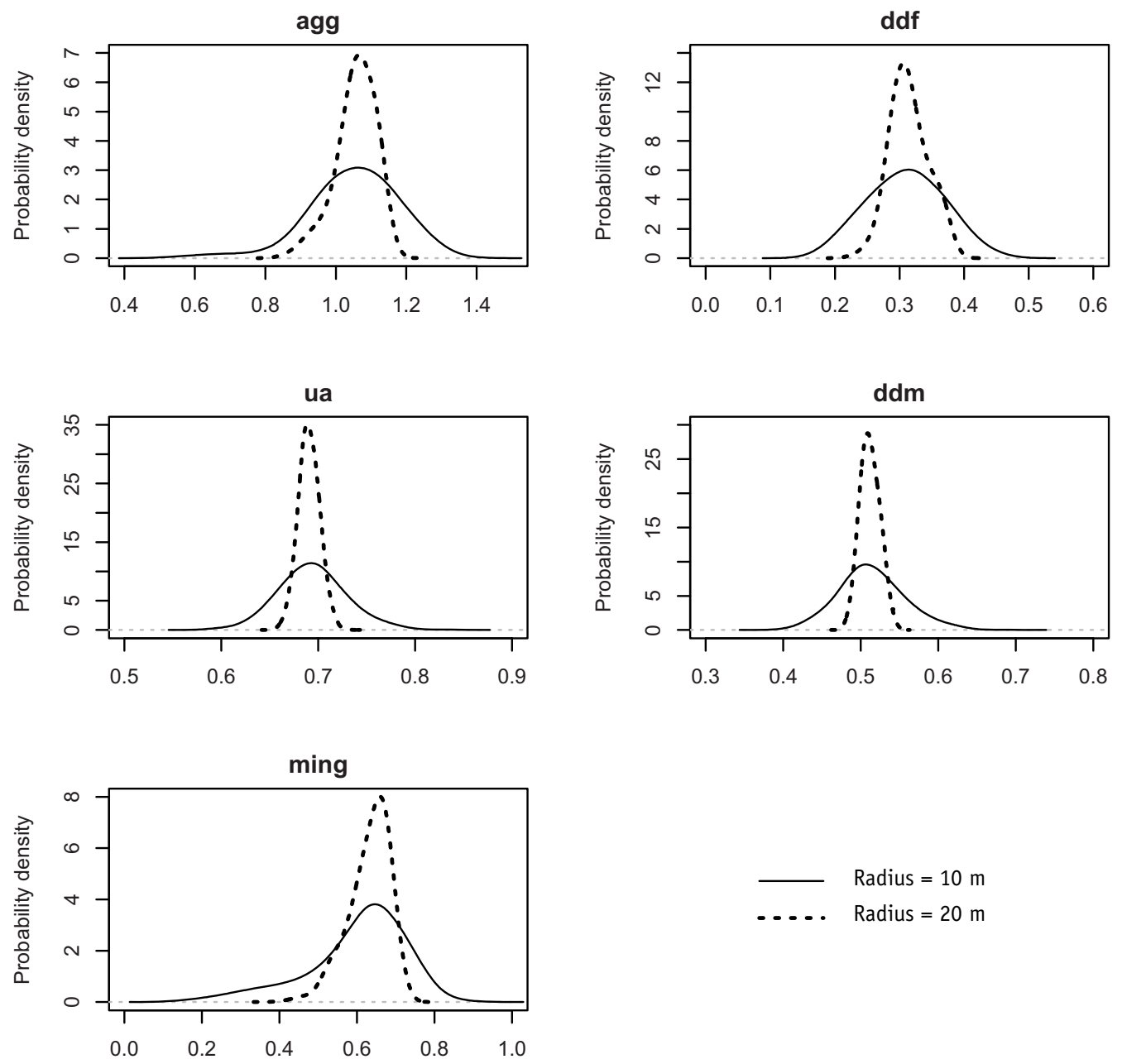

Figure 7. The probability density of structural indices for sample plots radii equal to $10 \mathrm{~m}$ (solid lines) and $20 \mathrm{~m}$ (dashed lines) in the RAMI reference stand.

Joonis 7. Puistu struktuuriindeksite valimhinnangute tõenäosustiheduse funktsioonid RAMI puistu andmeil proovitüki $10 \mathrm{~m}$ (pidevjoon) ja $20 \mathrm{~m}$ (katkendjoon) raadiuse korral.

and as it has been already discussed, several studies suggest that the bigger sample plots would result in more precise and accurate estimates (e.g. Johnson \& Hixon, 1952; Freese, 1960; Gray, 2003). Some other findings demonstrated that the spatial point patterns, other than random, may show different results (Reich \& Arvanitis, 1992), and the sampling errors as well as the differences of the mean estimates from the expected values could increase with increasing the plot size, depending on the stand structure and the management activities (Pommerening \& von Gadow, 2000; Kint et al., 2004). Consequently, when estimating different variables such as structural indices, special attention should be paid to the optimal size of the sample when considering the spatial distribution of the trees within the forest stands. On the other hand, as discussed earlier, the observation of a forest stand through sample 
plots with different sizes is a tricky issue because of spatial variablity of forest stands (Bellehumeur et al., 1997; Chen et al., 2004; Fajardo \& Gonzalez, 2009). As a spatial statistics tool the semivariogram is an applicable function to indicate the spatial correlation of variables characterizing the forest stand at sample locations (Cressie, 1993):

$r(r)=[2 N(r)]^{-1} \sum\left[X_{i}-X_{i+1}\right]^{2}$

where $X_{i}$ and $X_{i+r}$ are values of a variable at locations $i$ and $i+r$, separated by the vector of directional distance $\mathrm{r}$, and $\mathrm{N}(r)$ is the number of pairs of samples considered in the given distance class (lag, here $1 \mathrm{~m}$ ).

Figure 8 shows the omnidirectional semivariograms of the studied structural indices
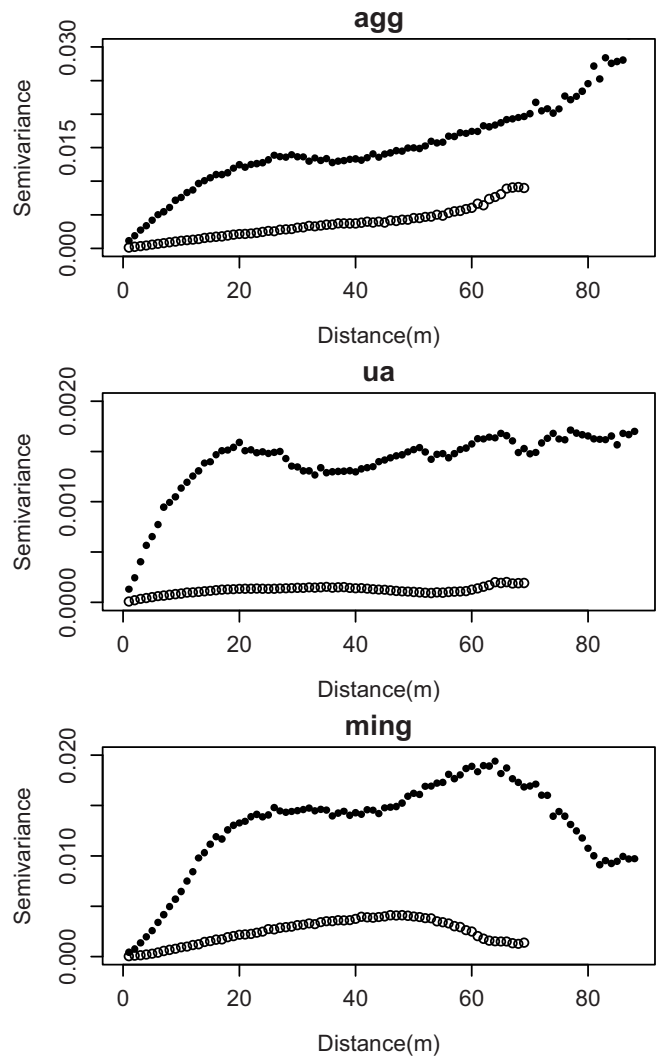

Figure 8. The omnidirectional semivariograms of the studied structural indices based on $10 \mathrm{~m}$ and $20 \mathrm{~m}$ sample plots' radii in the RAMI reference stand.

Joonis 8. RAMI puistu struktuuriindeksite igasuunalised semivariogrammid proovitüki $10 \mathrm{~m}$ ja $20 \mathrm{~m}$ raadiuse korral. based on $10 \mathrm{~m}$ and $20 \mathrm{~m}$ sample plots' radii in the RAMI stand. The spatial variability of all stand structure estimations change with the sample plot size, and a more significant spatial trend is seen for the smaller sample plots with radius of $10 \mathrm{~m}$, and also some degree of spatial auto-correlation of the stand structure appears for sample plots with a radius of $20 \mathrm{~m}$. Therefore, it can be concluded that observations at bigger spatial resolutions are more similar than of those at smaller scales (Arbia et al., 1996; Král et al., 2014), because the proportion of spatial components of variability increases with enlarging the sample plots and possible trends are then more visible (Bellehumeur $e t$ al., 1997; Cohen et al., 1990; Král et al., 2014). On the other hand, semivariograms are
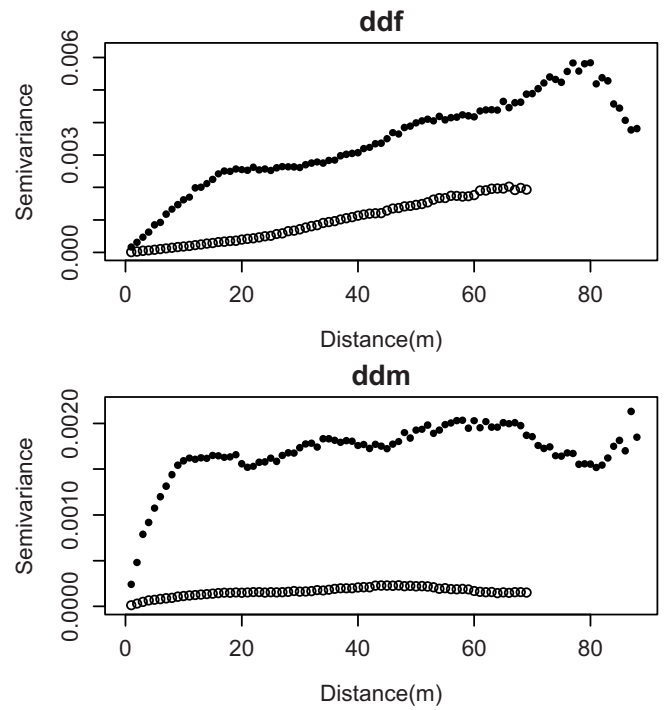

- Radius $=10 \mathrm{~m}$

O Radius $=20 \mathrm{~m}$ 
calculated either from discrete point data with a small extent (10-100 m) for tree level variables, or from sample plots of various sizes with a larger extent (150-300 m) for stand level measurements (Král et al., 2014). Subsequently, since the studied structural indices present different attributes of forest stand, it must be noted that for studying the spatial variability, the study area is quite small (one-hectare) and also homogeneous, and as is shown in Figure 8, the effects of the spatial correlation over short distances are non-negligible. Consequently, the calculated indices for different sample plots with any location are correlated, showing small variances. However, regarding the algorithms of calculated indices, they might be considered as tree level measures based on the tree's nearest-neighbours, accounting for small-scale differences (Kint et al., 2003) and, for describing a stand by a specific index, the mean value of that index for individuals within the stand (or sample plot) is calculated.

In summary, the study was carried out on a small and quite homogenous area, and because of that, the variations among the structural estimates of different sample plots, specifically within shorter distances, were small and spatially correlated. The effect of spatial autocorrelation is expected to be diminished by using multiple plots from entirely different stands, and consequently, the variation of estimates would probably increase, and be larger than the results of the current study. However, the trend of this increment strongly depends on the algorithm of structural indices and the spatial alignment of trees within the stands with different development stages, growth conditions and species compositions. Therefore, before generalizing the outcome of this study to other forest stands, a separate and careful evaluation of the structural indices is required in broader scales to depict the spatial correlation in observations measured at the sample locations.

\section{Conclusions}

The size and/or shape of the sampling plot is crucial to the extent that quantifying the same structural index for different sizes and/or shapes may yield different, or even inconsistent, results so that the appropriate size and shape of the sampling plot produce a high level of accuracy. The study results clearly demonstrated that the optimal choice of plot size and shape varies according to the spatial distribution of trees inside the stand and the algorithm of desired indices. The sensitivity of structural indices and characteristics to the size and shape of monitoring plots, was also demonstrated, where implementing square plots almost resulted in quite similar structural estimation accuracy compared to the accuracy estimations of circular plots. In addition, circular plots often provided satisfactory estimates of studied structural indices. On the other hand, not only should the sample plots be proper representatives of a real stand, but they also must be small enough, and simple to implement, in order to guarantee a minimum measurement expense. Therefore, referring to the results obtained for this study, circular plots are preferable, with the size depending on the stand attributes for structural considerations.

Acknowledgments. The study was supported by the European Commission's DG Joint Research Center (Ispra, Italy) for the collection of field data and the Estonian Research Council (ETF8890, IUT21-04). We are also sincerely grateful and would like to thank Dr. Mait Lang, who has kindly contributed to this research with recommendations and ideas. 


\section{References}

Adermann, V. 2010. Estonia (National forest inventory report). - Tomppo, E., Gschwantner, T., Lawrence, M., McRoberts, R.E. (eds.). National forest inventories: pathways for common reporting (NFI reports section). Heidelberg, Springer, 171-184.

Aguirre, O., Hui, G.Y., Gadow, K., Jiménez, J. 2003. An analysis of spatial forest structure using neighbourhood-based variables. - Forest Ecology and Management, 183, 137-145.

Albert, M. 1999. Analysis of thinning-induced changes in stand structure and modelling of thinnings in mixed-species stands. PhD Thesis, Faculty of Forestry and Forest Ecology, University of Göttingen. 195 pp.

Anselin, L. 1996. The Moran scatterplot as an ESDA tool to assess local instability in spatial association. - Fisher, M., Scholten, H., Unwin, D. (eds.). Spatial Analytical Perspectives on GIS. London, Taylor \& Francis, 111-125.

Arbia, G., Benedetti, R., Espa, G. 1996. Effects of the MAUP on image classification. - Geographical Systems, 3, 123-141.

Bellehumeur, C., Legendre, P., Marcotte, D. 1997. Variance and spatial scales in a tropical rain forest: changing the size of sampling units. - Plant Ecology, 130, 89-98.

Bobiec, A. 2002. Living stands and dead wood in the Bialowieza forest: suggestions for restoration management. - Forest Ecology and Management, $165,125-140$.

Boots, B.N., Getis, A. 1988. Point Pattern Analysis. Vol. 10. Newbury Park, CA: Sage Publications. 85 pp.

Burgman, M.A., Incoll, W., Ades, P.K., Ferguson, I., Fletcher, T.D., Wohlers, A. 1994. Mortality models for mountain and alpine ash. - Forest Ecology and Management, 67, 319-327.

Chen, J.Q., Song, B., Rudnicki, M., Moeur, M., Bible, K., North, M., Shaw, D.C., Franklin, J.F., Braun, D.M. 2004. Spatial relationship of biomass and species distribution in an old-growth Pseudotsuga-Tsuga forest. - Forest Science, 50, 364-375.

Churchill, D.J., Larson, A.J., Dahlgreen, M.C., Franklin, J.F., Hessburg, P.F., Lutz, J.A. 2013. Restoring forest resilience: from reference spatial patterns to silvicultural prescriptions and monitoring. - Forest Ecology and Management, 291, 442-457.

Clark, P.J., Evans, F.C. 1954. Distance to nearest neighbour as a measure of spatial relationships in populations. - Ecology, 35, 445-453.

Cohen, W.B., Spies, T.A., Bradshaw, G.A. 1990. Semivariograms of digital imagery for analysis of conifer canopy structure. - Remote Sensing of Environment, 34, 167-178.

Conkle, M. 1963. The determination of experimental plots size and shape in loblolly and slash pines. North California State University, School of Forestry. - Technology Report, 17, 51 pp.
Corona, P., Marchetti, M. 2007. Outlining multipurpose forest inventories to assess the ecosystem approach in forestry. - Plant Biosystem, 141, 243-251.

Corona, P., Saracino, A., Leone, V. 1998. Plot size and shape for the early assessment of post-fire regeneration in Aleppo pine stands. - New Forests, 16, 213-220.

Cressie, N.A. 1993. Statistics for spatial data. New York, John Wiley \& Sons. 900 pp.

Dale, M.R.T. 2000. Spatial patterns analysis in plant ecology. Cambridge University Press, Cambridge, United Kingdom. 326 pp.

Diggle, P.J. 1983. Statistical analysis of spatial point patterns. London, Academic Press. 148 pp.

Donnelly, K. 1978. Simulation to determine the variance and edge effect of total nearest neighbour distance. - Hodder, I.R. (ed.). Simulation methods in archaeology. Cambridge University Press, London, 91-95.

Eid, T., Tuhus, E. 2001. Models for individual tree mortality in Norway. - Forest Ecology and Management, 154, 69-84.

Fajardo, A., Gonzalez, M.E. 2009. Replacement patterns and species coexistence in an Andean Araucaria-Nothofagus forest. - Journal of Vegetation Science, 20, 1176-1190.

Fischer, A., Lindner, M., Abs, C., Lasch, P. 2002. Vegetation dynamics in central European forest ecosystems (near-natural as well as managed) after storm events. - Folia Geobotanica, 37, 17-32.

Franklin, J.F., Spies, T.A., Van Pelt, R., Carey, A.B., Thornburgh, D.A., Berg, D.R., Lindenmayer, D.B., Harmon, M.E., Keeton, W.S., Shaw, D.C., Bible, K., Chen, J. 2002. Disturbances and structural development of natural forest ecosystems with silvicultural implications, using Douglasfir forests as an example. - Forest Ecology and Management, 155, 399-423.

Frazer, G.W., Magnussen, S., Wulder, M.A., Niemann, K.O. 2011. Simulated impact of sample plot size and co-registration error on the accuracy and uncertainty of LiDAR-derived estimates of forest stand biomass. - Remote Sensing of Environment, 115(2), 636-649.

Freese, F. 1960. Testing accuracy. - Forest Science, 6(2), 139-145.

Frolking, S., Palace, M., Clark, D.B., Chambers, J.Q., Shugart, H.H., Hurtt, G.C. 2009. Forest disturbance and recovery - A general review in the context of space-borne remote sensing of impacts on aboveground biomass and canopy structure. - Journal of Geophysical Research, 114, G00E02.

Füldner, K. 1995. Mixed stands structure description. (Zur Strukturbeschreibung in Mischbeständen). Forstarchiv, 66, 235-240. (In German).

von Gadow, K., Hui, G.Y. 1999. Modelling Forest Development. Kluwer Academic Publishers, Dordrecht. 213 pp.

von Gadow, K., Hui, G. 2002. Characterizing forest spatial structure and diversity. - Bjoerk, L. (ed.). 
Proceedings IUFRO International Workshop: Sustainable Forestry in Temperate Regions. Lund, Sweden, 20-30.

von Gadow, K., Hui, G.Y., Albert, M. 1998. The neighbourhood pattern - a new parameter for describing forest structure. - Das Austrian Journal of Forest Science / Centralblatt für das gesamte Forstwesen, 115, 1-10.

Gleichmar, W., Gerold, D. 1998. Indexes for the description of the horizontal tree distribution. (Indizes zur Charakterisierung der horizontalen Baumverteilung). - Forstwissenschaftliches Centralblatt, 117, 69-80. (In German).

Gray, A. 2003. Monitoring stand structure in mature coastal Douglas-fir forests: effect of plot size. Forest Ecology and Management, 175, 1-16.

Haapanen, M. 1992. Effect of plot size and shape on the efficiency of progeny tests. - Silva Fennica, 26, 201-209.

Hui, G.Y., von Gadow, K. 2002. The optimal standard angle of the uniform angle index. - Zeitschrift für Forstwirtschaft und Forstwissenschaft, 173, 173177. (In German).

Hynynen, J., Niemisto, P., Vihera-Aarnio, A., Brunner, A., Hein, S., Velling, P. 2010. Silviculture of birch (Betula pendula Roth and Betula pubescens Ehrh.) in northern Europe. - Forestry, 83,103-119.

Johnson, F.A. Hixon H.J. 1952. The most efficient size and shape of plot to use for cruising in oldgrowth Douglas-fir timber. - Forestry, 50, 17-20.

Kint, V., De Wulf, R., Lust, N. 2004. Evaluation of sampling methods for the estimation of structural indices in forest stands. - Ecological Modelling, 180, 461-476.

Kint, V., Lust, N., Ferris, R., Olsthoorn, A.F.M. 2000. Quantification of forest stand structure applied to Scots pine (Pinus sylvestris L.) forests. - Investigación Agraria: Sistemas y Recursos Forestales, Fuera de Serie, 1, 147-163.

Kint, V., Van Meirvenne, M., Nachtergale, L., Geudens, G., Lust, N. 2003. Spatial methods for quantifying forest stand structure development: a comparison between nearest-neighbor indices and variogram analysis. - Forest Science, 49, 36-49.

Kiviste, A., Hordo, M., Kangur, A., Kardakov, A., Laarmann, D., Lilleleht, A., Metslaid, S., Sims, A., Korjus, H. 2015. Monitoring and modeling of forest ecosystems: the Estonian Network of Forest Research Plots. - Forestry Studies / Metsanduslikud Uurimused, 62, 26-38.

Král, K., Valtera, M., Janík, D., Šamonil, P., Vrška, T. 2014. Spatial variability of general stand characteristics in central European beech-dominated natural stands-Effects of scale. - Forest Ecology and Management, 328, 353-364.

Kuusk, A., Lang, M., Kuusk, J. 2013. Database of optical and structural data for the validation of forest radiative transfer models. -Kokhanovsky, A.A. (ed.). Radiative Transfer and Optical Properties of Atmosphere and Underlying Surface. BerlinHeidelberg, Springer, 109-148. van Laar, A., Akça, A. 2007. Forest mensuration. Springer, Dordrecht. 418 pp.

Law, R., Illian, J., Burslem, DFRP., Gratzer, G., Gunatilleke, CVS., Gunatilleke, IAUN. 2009. Ecological information fromspatial patterns of plants: insights from point process theory. Ecology, 97, 616-628.

Lingua, E., Cherubini, P., Motta, R., Nola, P. 2008. Spatial structure along an altitudinal gradient in the Italian central Alps suggests competition and facilitation among coniferous species. - Journal of Vegetation Science, 19, 425-436.

Lombardi, F., Marchetti, M., Corona, P., Merlini, P., Chirici, G., Tognetti, R., Burrascano, S., Alivernini, A., Puletti, N. 2015. Quantifying the effect of sampling plot size on the estimation of structural indicators in old-growth forest stands. Forest Ecology and Management, 346, 89-97.

Loo-Dinkins, J., Tauer, C. 1987. Statistical efficiency of six progeny tests field designs on three loblolly pine (Pinus taeda L.) site types. - Canadian Journal of Forest Research, 17, 1066-1070.

Martin, G.L., Ek, AR., Monserud, R.A. 1977. Control of plot edge bias in forest stand growth simulation models. - Canadian Journal of Forest Research, 7, 100-105.

Næsset, E., Bollandsås, O.M., Gobakken, T., Solberg, S., McRoberts, R.E. 2015. The effects of field plot size on model-assisted estimation of aboveground biomass change using multitemporal interferometric SAR and airborne laser scanning data. Remote Sensing of Environment, 168, 252-264.

Naumburg, E., DeWald, L.E. 1999. Relationships between Pinus ponderosa forest structure, light characteristics, and understory gRAMInoid species presence and abundance. - Forest Ecology and Management, 124, 205-215.

Navarro-Cerrillo, R.M., Manzanedo, R.D., Bohorque, J., Sánchez, R., Sánchez, J., Miguel, S.d., Solano, D., Qarro, M., Griffith, D., Palacios, G. 2013. Structure and spatio-temporal dynamics of cedar forests along a management gradient in the Middle Atlas. Morocco. - Forest Ecology and Management, 289, 341-353.

Palace, W.M., Sullivan, B.F., Ducey, M.J., Treuhaft, N.R., Herrick, C., Shimbo, J.Z., Mota-E-Silva, J. 2015. Estimating forest structure in a tropical forest using field measurements, a synthetic model and discrete return lidar data. - Remote Sensing of Environment, 161, 1-11.

Penttinen, A., Stoyan, D., Henttonen, H.M. 1992. Marked point process in forest statistics. - Forest Science, 38, 806-824.

Pommerening, A. 2002. Approaches to quantifying forest structures. - Forestry, 75, 305-324.

Pommerening, A., von Gadow, K. 2000. Among the possibilities and limits of detection structure with forest inventories. ( $\mathrm{Zu}$ den Möglichkeiten und Grenzen der Strukturerfassung mit Waldinventuren). - Forst und Holz, 55, 622-631. (In German). 
Pommerening, A., Stoyan, D. 2006. Edge-correction needs in estimating indices of spatial forest structure. - Canadian Journal of Forest Research, 36, 1723-1739.

Pommerening, A., Stoyan, D. 2006. Edge-correction needs in estimating indices of spatial forest structure. - Canadian Journal of Forest Research, 36, 1723-1739.

Reich, R.M., Arvanitis, L.G. 1992. Sampling unit, spatial distribution of trees, and precision. - Northern Journal of Applied Forestry, 9, 3-6.

Rice, A.H., Pyle, E.H., Saleska, S.R., Hutyra, L., Camargo, P.B., Portilho, K., Dulcyana, F.M., Steven, C.W. 2004. Carbon balance and vegetation dynamics in an old-growth Amazonian forest. - Ecological Applications, 14, 55-71.

Ripley, B.D. 1981. Spatial statistics. John Wiley \& Sons, New York.

Salk, C.F., Chazdon, R.L., Andersson, K.A. 2013. Detecting landscape-level changes intree biomass and biodiversity: methodological constraints and challenges of plot-based approaches. - Canadian Journal of Forest Research, 43, 799-808.
Sallabanks, R., Riggs, R.A., Cobb, L.E. 2002. Bird use of forest structural classes in grand fir forests of the Blue Mountains, Oregon. - Forest Science. 48, 311-321.

Tomppo, E. 1986. Models and methods for analysing spatial patterns of trees. - Communicationes Instituti Forestalis Fenniae, 138, 65 pp.

Travaglini, D., Fattorini, L., Barbati, A., Bottalico, F., Corona, P., Ferretti, M., Chirici, G. 2013. Towards a sampling strategy for the assessment of forest condition at European level: combining country estimates. - Environmental Monitoring and Assessment, 185, 3255-3268.

Unger, M., Homeier, J., Leuschner, C. 2013. Relationships among leaf area index, below-canopy light availability and tree diversity along a transect from tropical lowland to montane forests in NE Ecuador. - Tropical Ecology, 54, 33-45.

Wrigley, N., Holt, T., Steel, D., Tranmer, M. 1996. Analyzing, modeling, and resolving the ecological fallacy. - Longley, P., Batty, M. (eds.). Spatial Analysis: Modeling in GIS Environment. New York, John Wiley \& Sons, 23-30.

\title{
Proovitüki suuruse ja kuju mõju metsa struktuuriindeksite hinnangutele arukase (Betula pendula Roth) enamusega puistus Järvseljal
}

\author{
Kobra Maleki ja Andres Kiviste
}

Kokkuvõte

Metsa kirjeldamisel leiavad puistu traditsiooniliste takseertunnuste kõrval üha laiemat kasutamist mitmesugused puistu struktuuri ja puude ruumilise paiknemise mustrit iseloomustavad struktuuriindeksid ja karakteristikud. Eesti metsavarude hindamine ja kasvukäigu uurimine tugineb peamiselt suhteliselt väikestel proovitükkidel tehtavatele mõõtmistele (statistilise metsainventeerimise (SMI) proovitükid on raadiusega 7 või $10 \mathrm{~m}$, puistu kasvukäigu püsiproovitükkide võrgustiku (KKPRT) proovitükid on olenevalt puistu tihedusest raadiusega 15 kuni $25 \mathrm{~m}$ ), mistõttu tekib küsimus, millisel määral sõltuvad puistu struktuuri iseloomustavad näitajad proovitüki suurusest ja kujust.

Siinne uurimisala on ühe hektari $(100 \mathrm{~m}$ $\times 100 \mathrm{~m}$ ) suurune 54 aasta vanune arukase enamusega puistu (RAMI puistu) Järvselja Õppe- ja Katsemetskonna kvartalil JS228, millel asuvad puud mõõdeti ja kaardistati metsa kiirguslevi mudelite võrdlemise eesmärgil 2007. a. Puistus oli tehtud harvendusraie 2004. a. sügisel, mille käigus tekitati põhja-lõunasuunalised väljaveoteed. 2013. a tehtud kordusmõõtmisel oli uurimisalal 968 eluspuud, millest $57 \%$ olid arukased, 29,5\% sanglepad ja $11 \%$ haavad ning puude rinnasdiameetri ruutkeskmine oli $20,13 \mathrm{~cm}$. Erinevate struktuuriindeksite iseloomustamiseks ja omavaheliseks võrdlemiseks simuleeriti lisaks viis virtuaalset puistut, mis vastavad puude erinevatele paigutusmustritele metsas: (1) puude juhuslik paigutus ehk Poissoni protsess (Ran), (2) puude äärmuslik kobarpaigutus (Cl1) ja (3) puude mõõdukas kobarpaigutus $(\mathrm{Cl} 2)$, 
mis koostati kahetasemelise juhusliku liitprotsessi tulemusena, ning (4 ja 5) kaht tüüpi puude regulaarne paigutus (Reg1 ja Reg2). Simuleeritud puistutes järgiti RAMI puistu liigilist koosseisu ja rinnasdiameetri jaotust.

Puistu struktuuri kirjeldamiseks uuriti järgnevaid karakteristikuid: agregatsiooniindeksit (agg) (Clark \& Evans, 1954), diameetri diferentseerumisindeksit (ddf) (Füldner, 1995; Pommerening, 2002), diameetri domineerimisindeksit (ddm) (von Gadow \& Hui, 2002; Aguirre et al., 2003), puude paiknemisindeksit (ua) (Hui \& von Gadow, 2002) ja liikide segunemisindeksit (ming) (Füldner 1995; Aguirre et al., 2003) ning radiaaljaotuse funktsiooni $g(r)$ (Diggle, 1983). Agregatsiooniindeks (agg) ja diameetri diferentseerumisindeks (ddf) tuginevad lähima naaberpuu statistikale ning diameetri domineerimisindeks (ddm), puude paiknemisindeks (ua) ja liikide segunemisindeks (ming) nelja lähima naabri statistikale. Radiaaljaotuse funktsioon $\mathrm{g}(\mathrm{r})$ iseloomustab suvalisest punktist kaugusel r olevat puude tiheduse suhet puude tihedusse juhupaigutuse (Poissoni protsessi) korral ja on tõlgendatav sarnaselt agregatsiooniindeksiga (agg).

Proovitüki suuruse mõju uurimiseks vaadeldi 41 erineva raadiusega ringproovitükki alates raadiusest viis meetrit kuni raadiuseni 45 meetrit ühemeetrise sammuga. Iga proovitüki suuruse jaoks tekitati ühe hektari suuruse uurimisala kohta 1000 juhuslikult paigutatud proovitüki tsentrit nii, et proovitükid jääksid uurimisala sisse. Samu proovitüki tsentreid kasutati ka ruudukujuliste proovitükkide tekitamiseks. Iga proovitüki suuruse ja kuju jaoks arvutati puistu struktuuriindeksite oodatavad väärtused. Proovitüki suuruse ja kuju mõju struktuuriindeksite hinnangute täpsusele analüüsiti 1000 juhuvalimi hinnangute keskmiste ja standardhälvete abil. Tulemustest ilmnes, et puistu struktuuriindeksite hinnangud sõltuvad proovitüki suurusest ja kujust. Üldiselt vähenes struktuuriindeksite hinnangute varieeruvus (standardhälve) proovitüki suurenedes asümptootiliselt kõigi kuue puistu puhul. Erandiks oli puude paiknemisindeks (ua) regulaarse puude paigutusega puistutes (Reg1 ja Reg2), kus proovitükkidel saadud hinnangud olid alati täpsed. Sama pindala korral osutusid struktuuriindeksite hinnangud ringproovitükkidel mõnevõrra vähem varieeruvamaks kui ruudukujulistel proovitükkidel. See tendents ilmnes selgelt agregatsiooniindeksi (agg) hinnangutes regulaarse puude paigutusega puistutes (Reg1 ja Reg2). Struktuuriindeksite hinnangute keskmised erinevused oodatavatest väärtustest olid mõnevõrra vastuolulised, teatud punktimustrite juhtudel jäi isegi proovitüki suurenedes püsima mõningane erinevus struktuuriindeksi keskmise hinnangu ja oodatava väärtuse vahel. Radiaaljaotuse funktsioon g(r) RAMI puistul näitas, et kuni kauguseni $6 \mathrm{~m}$ on puud pigem regulaarse kui juhupaigutusega, kaugusel 6 kuni 10 m pigem kobarpaigutusega ja alates $10 \mathrm{~m}$ juhupaigutusega. RAMI puistu andmeil ilmnes selgelt, et kõigi töös käsitletud struktuuriindeksite hinnangud on $10 \mathrm{~m}$ raadiusega (SMI) proovitükkide puhul tunduvalt varieeruvamad kui $20 \mathrm{~m}$ raadiusega (KKPRT) proovitükkidel. Igasuunalise semivariogrammide analüüs viitab siiski asjaolule, et ühe hektari suurusel puistul esineb struktuuriindeksite hinnangute autokorrelatsioon, mistõttu suurel metsamaastikul võib üksteisest kaugel olevate proovitükkide struktuuriindeksite hinnangute varieeruvus olla mõnevõrra suurem, kui on esitatud selles uurimuses. 